\title{
Human Capital Management as a Resource in Achieving Competitive Advantage
}

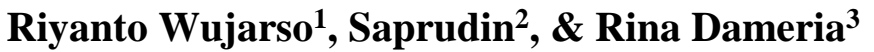 \\ ${ }^{1,2,3}$ Sekolah Tinggi Ilmu Ekonomi Jayakarta, Jakarta, Indonesia \\ riyanto.rw@gmail.com
}

\begin{abstract}
The aim is to provide the conceptual framework for the administration of human capital (MHC) and to show how human capital may be employed to secure the competitive advantage of an organization. Human capital is a concept referring to the extra value provided to organizations by humans. It stresses the necessity for strategic human capital investments through commitment, retention, talent management, and learning and development programs. These studies often mostly depend on an examination of the literature available for their data. Study results stress the relevance of human capital and the strategic measures that contribute to success and competitiveness.
\end{abstract}

\section{Keywords}

human capital

management; human resource management; competitive advantage

\section{Introduction}

Human resources as labor or employees play an important role in improving productivity and achievement of predetermined objectives (Ningsih, 2018). Schultz (1961) coined the term "human capital" and defined it as "all human abilities that develop into talents or learned and valuable features and can be added with the appropriate investment will become human capital." Barro (2001) defines human capital more precisely as representing an organization's human elements, a combination of intelligence, competence, and knowledge that distinguishes a business. The human aspect of an organization is comprised of individuals who can learn, develop, innovate, and provide creative motivation, which, The long-term sustainability of the business can be guaranteed if adequately motivated.

Human capital administration (HCM) focuses on data collection, analysis, and reporting supporting management levels and strategic value-added management in decision-making, investment, and operations. According to experts, the MHC demands a thorough analysis, assessment, and value assessment of human policies and practices. MHC is an approach defined by these specialists in human resources management; this is an area of significant strategic importance and is not allocated to HR, which regards it as an operational issue. (Coleman, 1998, Grossman, 2000).

Baron and Armstrong (2007) stress MHC's aim to quantify capital by defining the accumulation of knowledge, expertise, the skills required for both creativity and other critical labor traits and that MHC incorporates measures to quantify their value and skills to effectively manage organizations. MHC is often more broadly defined without a focus on measurement. Human capital management is a coordinated effort, according to Ingham (2007), to advance human capabilities for exceptional results. MHC is the full evolution and organizational value of human potential, according to Afiouni (2013). According to him, MHC is a human development philosophy focused on human value creation.

When answering four questions about value, scarcity, non-copying, and irreplaceability, a company is considered to have a competitive advantage (Barney, 2000). 
It is possible to increase the value of an organization by reducing the cost of a product or service or by differentiating products or services in a way that allows for higher pricing. A sustainable competitive advantage in a particular industry can be achieved by using three resources: physical, human, and organizational (Duschek, 2004). Competitors have demonstrated that two types of capital, physical capital, and organizational capital, can be duplicated and thus serve as sources of imitation. Reliability is one of the keys to gaining a competitive advantage. (Rengkung, 2015).

Though human capital is considered the primary strategic resource of the organization, unique contributions from every employee have also been acknowledged. Connecting human capital to a resource-based vision is facilitated by adding value in a distinctive manner (Khotimah, 2017). Even when an organization's internal resources cannot be replicated, they can provide sustainability for their business. The resource-based model asserts that the essential asset for a company to increase its competitiveness is to effectively manage the workforce.

\section{Research Methods}

This study utilized a literature review and qualitative methodologies. Qualitative research collects and analyzes non-numerical data such as text, video, or audio in order to gain a better understanding of a concept, view, or experience. It is a technique for gaining a thorough understanding of a research subject or for coming up with new ideas for a study project (Moloeng, 2007). Secondary data was gathered for research purposes from journal articles, textbooks, and various other published and unpublished sources. This article conducts a review of the literature on human capital (HC) and human resource management (HRM).

\section{Result and Discussion}

\subsection{Human Capital Management}

Human capital is essential, but unique contributions from every employee are equally important. Adding value distinctively is essential for connecting human capital to a resource-based vision (Khotimah, 2017). An organization's overall success relies as much on the number and quality of its internal resources as it does on the amount and quality of resources available outside. In the resource-based model, a company's most valuable asset is the ability to properly manage its workforce (Ruhana, 2012).

MHC is a workforce strategy that views people as tools (Human Capital) capable of assessing present value and enhancing future value through investment. MHC support organizations ensure that employees receive clear and consistent communication regarding performance objectives. Managers must evaluate, reward, and hold staff accountable for achieving defined business objectives, innovating, and developing their company's activities sustainably. MHC, as defined by Baron and Armstrong (2007), is a method for individuals who perform their most critical roles and have the most significant influence on the company's fundamental competencies to improve their performance. MHC assists decision-makers by developing the company's human resources strategy by combining business and workforce intelligence on how people and ideas can be effectively used to achieve critical business objectives such as increased revenue, cost reduction, process improvement, and increased technology investment. Linn et al. (2003) define MHC as a guarantee that society's enormous potential is connected to the company's mission and strategic goals, maximizing the company's value to stakeholders. 
The HRM approach is distinct from the work management approach, which aims to gain a competitive edge by integrating employee culture, structure, and strategy technology with a high level of commitment and capability. MHC is considered a "paradigm shift" in human resource management in comparison to the conventional approach. MHC approaches people as assets, whereas HRM views them as expenses (Mayo, 2001).

In HC and HR, whereas human resources are concerned with the work of individuals, the capacity and training which individuals have are more concerned with human capital. Human resources can also be defined as an organization that recruits skilled employees. In contrast, human capital is a measure of the skills needed by future staff by the Department of Human Resources (Sinambela, 2021; Sidiq \& Jalil, 2021). Another way to consider the distinction between HC and HR is to consider the various components of the two concepts. Human capital can be explained in material terms. Capital, in a broad sense, refers to an investment that has the potential to generate a return greater than the initial investment throughout its life. For instance, a factory can be considered a capital investment that generates returns for investors over the money invested in acquiring or establishing the factory and other operating costs. In a similar vein, capital investment in humans has the potential to generate dividends over the initial investment (Sudaryo et al., 2018).

MHC is addition and strengthening concept for HRM. It's not taking its place. Both MHC and HR are essential elements in the process of managing HR. In terms of the processes, but also the strategic approach and people-centered approach it brings to each process, MHC is comparable to human resources management. By enabling HR professionals to identify and focus on actual value creation activities, MHC raises human resources management to a new level.

Creating a culture that gives human capital a competitive advantage means more than just increasing recruitment or introducing new metrics. This is not an easy task, but it benefits the people who do it. In other words, they have a competitive advantage that is hard to copy (Lazear, 2009). Without the workers working on the machinery, equipment, inventory, and other assets, a corporation of the future would have no market worth. The real and future productivity machines of the future are human knowledge and skills. The widespread conviction is that a large part of the overall production capacity of a company may be accounted for in the case of current assets and fixed capital (Martin-de-Castro et al., 2006).

Highly skilled individuals can perform their jobs more efficiently, resulting in lower unit costs. The capabilities of workers, particularly their creativity, are enhanced due to $\mathrm{HC}$, resulting in more valuable products or services. According to Indrawati (2013), employee attitudes will influence customer satisfaction. Customer service is just as valuable as the connectivity of its employees. HC can help a company improve its performance by enabling it to understand and perform the quality, security, and timeliness complexities of different transferred business processes successfully. HC's specificity is a consequence of its rare and inimitable nature. Skills and human resources need to be developed and continuously updated, which is costly and impossible for all organizations, to make $\mathrm{HC}$ a scarceness of resources; tacit knowledge generated by social interactions makes HC a resource that cannot be replicated in a perfect fashion (Ongkoraharjo et al., 2008).

When HC is easily and quickly transferred between companies., competitors must be robust in preventing take-over attempts. Codified knowledge has an increased risk of expropriation because it is possible to articulate tacit knowledge. In contrast, it cannot be expressed or isolated from competition because it is incorporated into the organization's routines or human skills. In general, codified knowledge offers a competitive advantage 
only insofar as it is protected by the company. Knowledge can be so well protected against imitation that even the organization that created it is difficult to spread. The organizational and knowledge portion of $\mathrm{HC}$ is highly unique. $\mathrm{HC}$ is most valuable and unique in the environment where it was first developed and developed (optimally). HCs are contextualized and unique in their unrivaled characteristics (Bryner et al., 2014).

The organizations' ability to exploit the resource must be controlled to ensure that the characteristics of the $\mathrm{HC}$ organization provide a sustainable competitive advantage. For HCs to achieve full potential benefits, organizations must have systems and practices. The competitive advantage that results from creating long-term value is not the result of a oneoil component but is the result of a combination, encouraging, encouraging, and rewarding the implementation of human resource development elements, strategically relevant components, and resource management systems. MHC, based on HC, assumes that it is unique, inimitable, precious, and irreplaceable due to its singularity to every company as a source of competitive advantage.

\subsection{Human Capital as an Advantage Resource}

It requires more than a quick fix in a control-oriented organization to turn human capital into a competitive advantage (Poulakan.et.all, 2019). This calls for the right people to be attracted and retained, and effectively managed. It is not easy to attract and retain the right people, but most organizations can do it with sufficient resources. Another story is how organizational structures and operating systems are developed and implemented that make human resources an enterprise source or competitive source of value. A proper management comfortability and design of most of the main operating systems must create a human capital-centric organization.

Corporate leaders in HC-centered organizations, in the management of human resources, can and should do a lot. Leaders should assess the efficiency of the human resources management system of their organization and their employees' status. Leaders need to understand as much as they do about the financial and physical assets of their organization's human resources. Leaders need metrics that reflect the human resources situation of the organization accurately. They also need analyzes to show how management metrics affect the performance of the business. You must use the data to make strategic choices, assess senior managers and make decisions for your organizations on the design, change, and effectiveness (Riniwati, 2016).

Top Managers certainly are crucial to the efficiency of a firm. The quality of a Top Manager of an organization, senior executives, and employee motivation and satisfaction has a direct impact on corporate performance. staff Staff (Tucunan et al, 2014). Leadership is only one of the main factors that affect the effectiveness of an organization. A series of studies show that most of the employee behavior is not determined primarily by the Top Manager or senior management but by the behavior of the supervisor or the supervisor of the employee. These are the people who can give the organization's members today the most critical motivation and guidance (Nulhaqim, et.all, 2019). These managers acquire and distribute technical and organizational knowledge concerning strategy implementation, change management, and work processes. They are also people whose behavior significantly shapes the culture in a manner that does not influence senior management behavior.

Human resources have the primary function of strengthening corporate performance by enhancing management behavior and the quality of management of human resources and decision making on the organization. Human resources experts at all levels of the organization cannot and must not manage and lead individuals what human resources can 
and should be done to boost leadership and management performance. It can also help design and implement a strategy and provide a clear and significant added value for a company whose people capital is its most important asset.

Most well-run organizations' financial information systems provide an ideal baseline for evaluating information systems on human resources. Human capital information systems must pay the same attention and accuracy as financial reporting systems to physical asset measurements to measure human capital cost, performance, and condition. Information systems must monitor and report on the performance of an organization in essential sectors where human capital is the primary determinant of efficiency. They cannot just provide conventional financial data because they often deceive high-capital firms. A metric must be used to track the efficiency, production, condition, and value of the talent.

MHC helps to increase the performance of an organization. Better-prepared individuals and a more suitable work environment are available from companies with a more significant concentration of HC (Boon et al., 2018), making integration between humans and culture more straightforward. Organizations can conceptualize different contracting requirements, efficiently carry out and supply transferred processes, act on real-time feedback and learn from them, and develop new ways to work through the employees' formal training, work-based knowledge, and relevant work experience. And conduct sometimes, even better, business. This training should, once again, focus on the integration of the inner resources of the organization so that the specific skills necessary for the effective management of the internal resources are provided. All this might gradually increase the quality of services given and create leases (Boon et al., 2018).

MHC contributes to an organization's performance. Better-prepared personnel and a more adapted work environment are accessible in firms with a higher proportion of $\mathrm{HC}$ (Boon et al., 2018). Organizations can envision various contractual needs, carry out and provide transferable processes quickly, act on and learn from real-time feedback, and establish new methods of working through employee training, expertise based on their jobs, and appropriate work experience. And occasionally do business, even better. This training should again focus on integrating the organization's internal resources so that the specialized skills needed for effective internal resource management are imparted. This could progressively improve the quality of services and produce rentals (Benevene \& Cortini, 2010).

In other words, when strategic managers have an organizational grasp of dynamic resources and capabilities, key investments can be better managed; in other words, increased management expertise can assist mitigate the link between $\mathrm{R}$ and $\mathrm{D}$ deployment and value creation. HC must be incorporated in the procedure to optimize performance. Core competencies that can help improve the company's performance are necessary at the organizational level. The management of human resources organized around essential skills affects performance. Because $\mathrm{HC}$ is a scarce resource, performance is difficult to enhance directly. Only when applied and successfully translated to the particular work at hand, can HC boost its performance. These duties are performed with the help of tools given by companies. 


\section{Conclusion}

In today's knowledge-based economy, humanity is more critical. Human capital is essential for survival and competitive advantage in a changing environment. Organizations place a premium on $\mathrm{HC}$ because they believe that $\mathrm{HC}$ is the only way to achieve a competitive advantage. Additionally, competitors find it difficult to replicate equal employees in every area because each company's employees are unique and can be distinguished from their competitors. Organizations are now attempting to boost employee performance through the effective implementation of human resource policies. The company will concentrate its human resources efforts on improved decision-making, effective communication, and new and innovative ideas throughout the organization. To ensure that employees have an adequate competitive advantage, the company's business strategy and human resource practices must first be analyzed. A comprehensive human resource management model and collaborative working relationship should be established, and businesses should also promote long-term thinking, core talent development, and analytical knowledge. The administration of human resources should be considered as a strategic activity that conforms to the overall strategy of the firm. The development and maintenance of a competitive benefit depend on human resources. The development of human resources is not the sole duty of the Department of Human Resources. The ability to build a positive atmosphere depends on innovation and creativity in the organizations. All are considered to be the same, but distinguished human capital requires high management sanctions as a competitive advantage.

\section{References}

Afiouni, F. (2013). Human Capital Management: A New Name for HRM?. International Journal of Learning and Intellectual Capital, 10(1), 18-34.

Agung, A. L. (2013). Human Capital Competencies. Elex Media Komputindo.

Barney, J. B. (2000). Firm Resources and Sustained Competitive Advantage. in Economics Meets Sociology in Strategic Management. Emerald Group Publishing Limited.

Baron, A., \& Armstrong, M. (2007). Human Capital Management: Achieving Added Value Through People. Kogan Page Publishers.

Barro, R. J. (2001). Human Capital and Growth. American Economic Review, 91(2), $12-$ 17.

Benevene, P., \& Cortini, M. (2010). Interaction Between Structural Capital And Human Capital In Italian Npos: Leadership, Organizational Culture, And Human Resource Management. Journal Of Intellectual Capital, 11(2), 123-139.

Boon, C., Eckardt, R., Lepak, D. P., \& Boselie, P. (2018). Integrating Strategic Human Capital And Strategic Human Resource Management. The International Journal of Human Resource Management, 29(1), 34-67.

Brymer, R. A., Molloy, J. C., \& Gilbert, B. A. (2014). Human Capital Pipelines: Competitive Implications of Repeated Interorganizational Hiring. Journal of Management, 40(2), 483-508.

Coleman, J. S. (1988). Social Capital in The Creation of Human Capital. American Journal of Sociology, 94, S95-S120.

Duschek, S. (2004). Inter-Firm Resources And Sustained Competitive Advantage. Management Revue, 53-73.

Grossman, M. (2000). The Human Capital Model. In Handbook of Health Economics (Vol. 1, pp. 347-408). Elsevier. 
Indrawati, A. D. (2013). Pengaruh kepuasan kerja terhadap kinerja karyawan dan kepuasan pelanggan pada rumah sakit swasta di kota denpasar. Matrik: Jurnal Manajemen, Strategi Bisnis dan Kewirausahaan.

Ingham, J. (2007). Strategic Human Capital Management. Routledge.

Khotimah, K. (2017). Pandangan Berbasis Sumber Daya (RBV) Dalam Pembahasan Organisasi Ekonomi. Future: Jurnal Manajemen dan Akuntansi, 5(1), 31-41.

Lazear, E. P. (2009). Firm-Specific Human Capital: A Skill-Weights Approach. Journal Of Political Economy, 117(5), 914-940.

Lin, C., Yu-Ping Wang, C., Wang, C. Y., \& Jaw, B. S. (2017). The Role of Human Capital Management in Organizational Competitiveness. Social Behavior and Personality: An International Journal, 45(1), 81-92.

Martín-de-Castro, G., Navas-López, J. E., López-Sáez, P., \& Alama-Salazar, E. (2006). Organizational Capital as Competitive Advantage of The Firm. Journal of Intellectual Capital.

Mayo, A. (2001). The Human Value of The Enterprise. London: Nicholas Brealey Publishing.

Moloeng, L. J. (2007). Metodologi Penelitian Kualitatif Edisi Revisi. Bandung: Remaja Rosdakarya.

Ningsih, S. (2018). The Relationship Between Motivation and Worker's Productivity in Civil Registration and Population Department, Asahan Regency, Indonesia. Budapest International Research and Critics Institute-Journal (BIRCI-Journal). P. 148-160.

Nulhaqim, S. A., \& Sulastri, S. (2019). Analisis Faktor Eksternal Dan Faktor Internal Organisasi Pelayanan Sosial Relawan Muda Riau. JISPO Jurnal Ilmu Sosial dan Ilmu Politik, 9(1), 155-170.

Ongkorahardjo, M. D. P. A., Susanto, A., \& Rachmawati, D. (2008). Analisis Pengaruh Human Capital Terhadap Kinerja Perusahaan (Studi Empiris pada Kantor Akuntan Publik di Indonesia). Jurnal Akuntansi dan Keuangan, 10(1), 11-21.

Poluakan, M. V., Dikayuana, D., Wibowo, H., \& Raharjo, S. T. (2019). Potret Generasi Milenial pada Era Revolusi Industri 4.0. Focus: Jurnal Pekerjaan Sosial, 2(2), 187197.

Rengkung, L. R. (2015). Keuntungan Kompetitif Organisasi dalam Perpsektif Resources Based View (RBV). AGRI-SOSIOEKONOMI, 11(2A), 1-12.

Riniwati, H. (2016). Manajemen Sumberdaya Manusia: Aktivitas Utama dan Pengembangan SDM. Universitas Brawijaya Press.

Ruhana, I. (2012). Pengembangan Kualitas Sumber Daya Manusia Vs Daya Saing Global. PROFIT: Jurnal Administrasi Bisnis, 6(1).

Schultz, T. W. (1961). Investment in Human Capital. The American Economic Review, 51(1), 1-17.

Sidiq, R. S. S., \& Jalil, A. (2021). Virtual World Solidarity: How Social Solidarity is Built on the Crowdfunding Platform Kitabisa.com. Webology, 18(1).

Sinambela, L. P. (2021). Manajemen Sumber Daya Manusia: Membangun Tim Kerja Yang Solid Untuk Meningkatkan Kinerja. Bumi Aksara.

Sudaryo, Y., Aribowo, A., \& Sofiati, N. A. (2018). Manajemen Sumber Daya Manusia: Kompensasi Tidak Langsung dan Lingkungan Kerja Fisik. Andi.

Tucunan, R. J. A., Supartha, W. G., \& Riana, I. G. (2014). Pengaruh Kepemimpinan Transformasional terhadap Motivasi dan kinerja Karyawan. E-jurnal ekonomi dan Bisnis Universitas Udayana, 3(09), 533-550. 